\title{
Controlled study of autoimmunization against liver in inbred rat strains ${ }^{1}$
}

\author{
B. P. MACLAURIN
}

From the Department of Medicine, University of Otago Medical School, Dunedin, New Zealand

SUMMARY By prolonged immunization of an inbred rat strain with isologous liver homogenate in Freund's complete adjuvant a low grade autoimmune 'cholangitis' with periductular fibrosis has been demonstrated. The lesion could be transferred to isogeneic animals by serial spleen cell injections and was associated with mild but variable delayed skin sensitivity to a supernatant fraction of the liver homogenate. It is thought to be due to a combined cellular and antibody-mediated immune response, directed against bile duct constituents. Pulmonary (peribronchial) lesions have also been described in the same animals and are considered to be of similar origin and to represent a cross reaction with tissue of similar embryological (entodermal) origin. This appears to be the first description of periductular hepatic fibrosis clearly resulting from an autoimmune reaction and may provide a model for further study of rather similar histological reactions known to occur in man.

In previous reports (Maclaurin and Humm, 1968 and 1969) it has been demonstrated that a low-grade portal triaditis can be induced in rats by repeated injections of homologous liver homogenate in complete Freund's adjuvant, and that this liver lesion can be transferred to isogeneic normal rats by intravenous injections of spleen cell suspensions from the immunized animals. These findings suggested that the liver lesion might result, in part at least, from a cell-mediated immune attack on the liver, and a similar conclusion has been drawn by Scheiffarth, Warnatz, Wolf, and Schmidt (1967b) on the basis of analogous experiments with mice. However, in the studies referred to, histological examination was not controlled by blind assessment of coded specimens and the number of control series was rather limited. The present paper represents an attempt to remedy these deficiencies and to quantitate precisely the liver changes induced. In addition, an assessment for delayed skin hypersensitivity to the liver antigen has been made and associated histological changes in other organs have been evaluated. These controlled observations are considered to confirm the earlier tentative conclusion, that a partly cell mediated portal triaditis can be induced in rats,

${ }^{1}$ The material in this paper was presented in part at the London meeting of the British Society for Immunology (April, 1970) and at an international meeting at King's College Hospital, London, in July 1970, devoted to immunological aspects of liver diseases.

Received for publication 3 November 1970. by immunization with a liver homogenate. Some evidence of immune damage to bronchial mucosa was also observed. The significance of this possible entodermal cross reaction is discussed in relation to other autoimmune tissue damage.

\section{Methods}

RAT STRAINS EMPLOYED

As in the previous studies, the same two pure rat strains designated $\mathrm{AS}_{2}$ and $\mathrm{BS}$ were used. These animal strains have been shown to differ at the major histocomparability locus AgB (Heslop, 1968). $F_{1}$ hybrid animals derived from these strains are designated $\mathrm{AS}_{2} \mathrm{BSF}_{1}$.

DESIGN OF EXPERIMENTAL GROUPS

Details of the groups are set out in Table I. There were three main categories.

\section{Direct immunization}

Groups A, B, C, and D were immunized for varying periods with liver homogenate from different rat strains emulsified in complete Freund's adjuvant.

\section{Controls}

Group $\mathrm{E}$ was untreated and animals were aged 6 months at the time of sacrifice. Group $F$ received an approximately equivalent number of injections of 


\begin{tabular}{|c|c|c|c|c|c|c|c|c|c|}
\hline \multirow[t]{2}{*}{ Group } & \multirow[t]{2}{*}{ No. of Animals } & \multicolumn{2}{|c|}{ Mean Age (mth) } & \multicolumn{3}{|c|}{ Liver Homogenate } & \multicolumn{3}{|c|}{ Spleen Cell Suspension } \\
\hline & & At Start & At Finish & $\begin{array}{l}\text { Source } \\
\text { Strain }\end{array}$ & $\begin{array}{l}\text { No. of } \\
\text { Injections }\end{array}$ & $\begin{array}{l}\text { Complete } \\
\text { Freund's } \\
\text { Adjuvant } \\
\text { Used }\end{array}$ & Source & $\begin{array}{l}\text { No. of } \\
\text { Cells } \\
\text { Injected }\end{array}$ & Sonicated \\
\hline $\begin{array}{l}\text { Direct Liver } \\
\text { Immunization } \\
\text { A } \\
\text { B } \\
\text { C } \\
\text { D }\end{array}$ & $\begin{array}{l}6 \\
6 \\
4 \\
4\end{array}$ & $\begin{array}{l}3.0 \\
1.0 \\
3.0 \\
2.0\end{array}$ & $\begin{array}{l}6.5 \\
3.5 \\
5.5 \\
4 \cdot 5\end{array}$ & $\begin{array}{l}\text { AS,BS } \\
\text { AS, BS } \\
\text { AS, }_{2} \\
\text { BS }\end{array}$ & $\begin{array}{l}16 \\
13 \\
10 \\
10\end{array}$ & $\begin{array}{l}\text { Yes } \\
\text { Yes } \\
\text { Yes } \\
\text { Yes }\end{array}$ & $\begin{array}{l}= \\
z\end{array}$ & $\begin{array}{l}\bar{z} \\
\bar{z}\end{array}$ & $\begin{array}{l}\text { No } \\
\text { No } \\
\text { No } \\
\text { No }\end{array}$ \\
\hline $\begin{array}{l}\text { Controls } \\
\text { E (untreated) } \\
\text { F (with adjuvant) }\end{array}$ & $\begin{array}{l}5 \\
6\end{array}$ & $\overline{3 \cdot 5}$ & $\begin{array}{l}6.0 \\
5.5\end{array}$ & - & $\overline{12}$ & $\begin{array}{l}\text { No } \\
\text { Yes }\end{array}$ & - & - & $\begin{array}{l}\text { No } \\
\text { No }\end{array}$ \\
\hline $\begin{array}{l}\text { Spleen Cell Transfer } \\
\text { G (immunized cells) }\end{array}$ & 11 & 0.25 & $2 \cdot 5$ & - & - & No & $\begin{array}{l}\text { Groups } \\
\text { A and B }\end{array}$ & $\begin{array}{l}25,000,000 \\
\times 3\end{array}$ & $\begin{array}{l}\text { No } \\
\text { Yes }\end{array}$ \\
\hline H (sonicated cells) & 6 & 0.25 & 2.5 & - & - & $\begin{array}{l}\text { No } \\
\text { No }\end{array}$ & $\begin{array}{l}\text { Groups } \\
\text { A and B } \\
\text { Group E }\end{array}$ & $\begin{array}{l}25,000,000 \\
\times 3 \\
25,000,000\end{array}$ & $\begin{array}{l}\text { Yes } \\
\text { No }\end{array}$ \\
\hline
\end{tabular}

Table I Experimental groups of $A S_{2}$ recipient rats

complete Freund's adjuvant in equal dosage, but without liver homogenate.

\section{Spleen cell transfer experiments}

Group $\mathbf{G}$ animals received three injections each, of approximately 25 million spleen cells in suspension each time. The first injection was made into the peritoneal cavity, and the remainder intravenously at intervals of three weeks. The spleen cells were obtained from animals of the A and B Groups at the time of sacrifice.

Group $\mathbf{H}$ animals were treated similarly, but the spleen cell suspension was sonicated for two minutes before injection and microscopic examination confirmed that very few whole cells remained in the suspension. Animals in group $\mathbf{K}$ were also treated in the same manner as those in group $G$, but the spleen cell suspension for injection was derived from animals of the control series (group E).

\section{PREPARATION OF LIVER HOMOGENATE}

Whole rat livers weighing approximately $8 \mathrm{~g}$ were homogenized with $4 \mathrm{ml}$ of Hank's balanced salt solution in a Potter glass homogenizer. The homogenate was poured, without filtration, into a sterile bijou bottle leaving any fibrous residue behind. A water-in-oil emulsion in $1.5 \mathrm{ml}$ of Freund's complete adjuvant (Difco) was obtained by repeated forceful injection of the homogenate beneath the surface of the adjuvant contained in a second sterile bijou bottle. Doses $(0.5 \mathrm{ml})$ of this emulsion were injected twice weekly, immediately after preparation, into recipients alternating between the intramuscular and intraperitoneal routes. A final boosting injection without adjuvant was given two weeks after the injection course for each series, and animals were sacrificed 10 to 14 days later.

PREPARATION OF SPLEEN CELL SUSPENSIONS These were prepared by brief gentle homogenization of a whole rat spleen in a Potter glass homogenizer with $0.7 \mathrm{ml}$ of Hank's balanced salt solution. The homogenate was strained through fine steel mesh. A cell count was performed in a haemocytometer chamber, and the suspension was adjusted if necessary so that $0.1 \mathrm{ml}$ contained approximately $25 \times$ $10^{6}$ lymphocytes. The cell suspension was taken up in a tuberculin syringe and injected through a size 25 needle. All manipulations were carried out with strict asepsis.

\section{ANAESTHESIA}

Light ether anaesthesia was employed for the tail vein intravenous injections in the spleen cell transfer groups, but was not required for the remainder of the injection programme.

\section{SKIN TESTING}

Liver homogenate, freshly prepared as for liver immunization in each series, and from the appropriate rat strain, was centrifuged at $5,000 \mathrm{rpm}$ for 15 minutes at $0^{\circ} \mathrm{C}$. The supernatant obtained was used for skin testing each animal of that series. It was injected intradermally on one side of the back, in a dose of $0.05 \mathrm{ml}$ after closely clipping the hair and cleansing the skin with alcohol. On the opposite side of the back, a similar injection of normal saline, $0.05 \mathrm{ml}$, was made. Skin tests were assessed at 
4,24 , and 48 hours, using a pair of skin calipers to determine the thickness of the skin at the injection sites. In some groups, an additional assessment was made at 20 hours.

\section{HISTOLOGICAL EXAMINATION}

A full necropsy was carried out on most animals of groups A and B. For the remaining groups, only the liver and lungs were routinely sectioned. The lung was prepared for sectioning by initial distension with $10 \%$ formalin. Two days later, coronal cuts through the lung were made to include the hilar region and major bronchi. Sections were obtained from two liver lobes for each animal and fixed in $10 \%$ formalin as were all other tissues examined. Liver sections were prepared with haematoxylin and eosin and van Giesen stains, but other tissues were stained only with the former. After a preliminary review to determine the main features present all sections were coded by the laboratory assistant and read blind. The rats were sacrificed by exsanguination and the serum was separated and stored deep frozen for later antibody assessment. Body weights and liver and spleen weights were recorded for each animal at this time. Wherever possible, a numerical assessment of positive features was attempted with scoring on the following basis: doubtful positive = 1 ; definite positive $=2$; strong positive $=4$; very strong positive $=6$. In this way, a mean score was obtained for each group for various histological attributes.

\section{Results}

The histological and other results are shown in summary form in Table II.

\section{LIVER HISTOLOGY}

Deposition of new fibrous tissue about the small and large bile ducts was the most obvious abnormality in those animals directly immunized with liver and this was also clearly apparent-though less markedin those animals injected with liver-immunized spleen cells. The appearances seen are illustrated in Fig. 1a and should be compared with the appearance of a portal tract from an untreated control animal (Fig. 1b). Animals treated with adjuvant only resembled the untreated controls and showed no increase in fibrous tissue, and the same was true of animals in group $\mathrm{K}$ injected with normal spleen cells. In animals in which periductular fibrosis was well marked, there was often distortion of the ducts with reduplication and sometimes obvious disruption or complete replacement with fibrous tissue (Fig. 2). The distribution of these changes paralleled that of fibrous tissue alone in the various experimental groups but to a lesser degree. However, only minor bile duct changes were seen in the animals which received sonicated immune spleen cells and these appearances did not differ significantly from those noted in the control groups.

Some increase in the numbers of lymphocytes in the portal tracts and infiltrating the walls of involved bile ducts was noted; it was associated with the periductular fibrosis seen in groups $\mathbf{A}$ and $\mathbf{C}$ and in the control group treated with adjuvant alone (group F) but not in any of the other groups of animals. The former groups (direct liver immunized) showed the maximum degree of periductular fibrosis observed, and although the lymphocytic infiltration may be mainly attributable to the adjuvant, it was not seen in all the groups treated with adjuvant. Furthermore, whenever periductular fibrosis was observed,

\begin{tabular}{|c|c|c|c|c|c|c|}
\hline \multirow[t]{3}{*}{ Group } & \multicolumn{4}{|c|}{ Liver Histology ${ }^{1}$} & \multirow{2}{*}{\multicolumn{2}{|c|}{$\begin{array}{l}\text { Skin Test with Liver Homogenate } \\
\text { Supernatant (mean thickness at } 48 \mathrm{hr} \\
\text { in mm) }\end{array}$}} \\
\hline & \multirow{2}{*}{$\begin{array}{l}\text { Periductular } \\
\text { Fibrosis }\end{array}$} & \multirow{2}{*}{$\begin{array}{l}\text { Bile Duct } \\
\text { Damage }\end{array}$} & \multirow{2}{*}{$\begin{array}{l}\text { Portal } \\
\text { Lymphocytic } \\
\text { Infiltrate }\end{array}$} & \multirow{2}{*}{$\begin{array}{l}\text { Kupffer Cell } \\
\text { Increase }\end{array}$} & & \\
\hline & & & & & Test & Control \\
\hline \multicolumn{7}{|l|}{$\begin{array}{l}\text { Direct Liver } \\
\text { Immunization }\end{array}$} \\
\hline $\begin{array}{l}\mathbf{A} \\
\mathbf{B} \\
\mathbf{C} \\
\mathbf{D}\end{array}$ & $\begin{array}{l}2.5 \\
1.3 \\
4 \cdot 0 \\
1.0\end{array}$ & $\begin{array}{l}1.5 \\
0.2 \\
1.0 \\
0\end{array}$ & $\begin{array}{l}2 \cdot 7 \\
1 \cdot 3 \\
3 \cdot 4 \\
1.5\end{array}$ & $\begin{array}{l}1 \cdot 8 \\
2.7 \\
2.5 \\
1.0\end{array}$ & $\begin{array}{l}3 \cdot 3 \\
3 \cdot 0 \\
2 \cdot 4 \\
2 \cdot 0\end{array}$ & $\begin{array}{l}2.0 \\
1.9 \\
2.0 \\
1.7\end{array}$ \\
\hline $\begin{array}{l}\text { Controls } \\
\text { E (untreated) } \\
\text { F (with adjuvant) }\end{array}$ & $\begin{array}{l}1.0 \\
1.0\end{array}$ & $\begin{array}{l}0 \\
0.5\end{array}$ & $\begin{array}{l}1.5 \\
3.0\end{array}$ & $\begin{array}{l}1 \cdot 0 \\
2 \cdot 0\end{array}$ & $\begin{array}{l}2 \cdot 3 \\
2 \cdot 2\end{array}$ & $\begin{array}{l}2.0 \\
2.0\end{array}$ \\
\hline $\begin{array}{l}\text { Spleen Cell Transfer } \\
\mathbf{G} \text { (immunized cells) } \\
\mathbf{H} \text { (sonicated cells) } \\
\mathbf{K} \text { (normal cells) }\end{array}$ & $\begin{array}{l}1.8 \\
17 \\
0.5\end{array}$ & $\begin{array}{l}1 \cdot 1 \\
03 \\
0 \cdot 4\end{array}$ & $\begin{array}{l}1.6 \\
1.8 \\
1.6\end{array}$ & $\begin{array}{l}1.2 \\
1.0 \\
1.0\end{array}$ & $\begin{array}{l}25 \\
2.1 \\
-\end{array}$ & $\begin{array}{l}21 \\
1.8 \\
-\end{array}$ \\
\hline
\end{tabular}

Table II Mean scores for liver histology and skin test thickness

'Scoring: doubtful positive $=1$; definite positive $=2$; strong positive $=4$; very strong positive $=6$. 


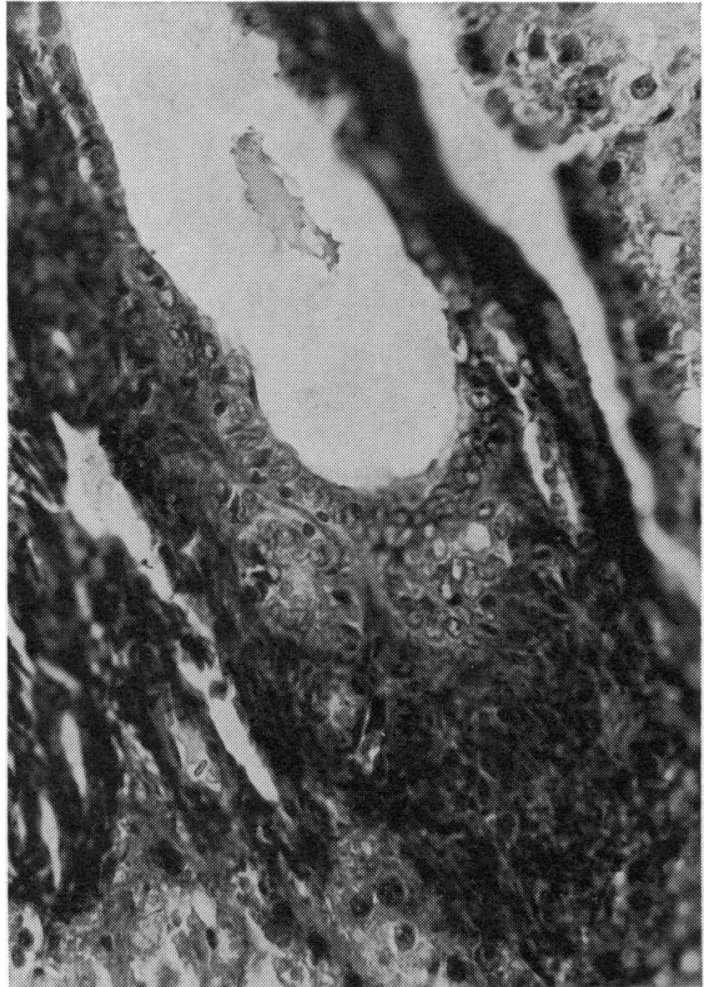

Fig. 1a.

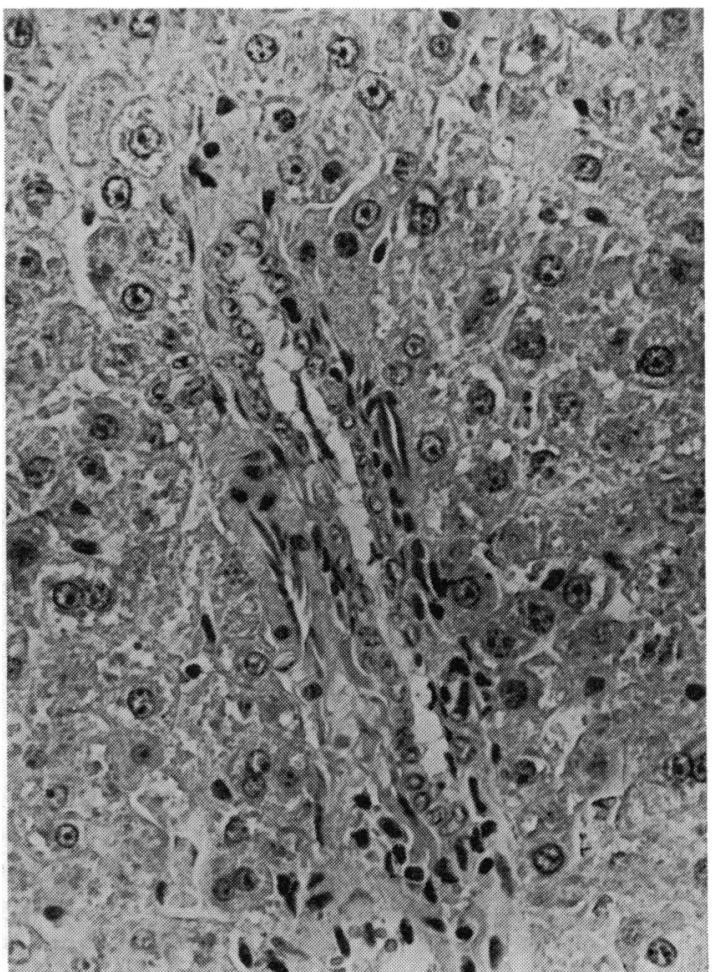

Fig. 1b.

Fig. 1a Marked fibrotic reaction surrounding a large bile duct which shows some mucosal irregularity and reduplication. The section is from a directly immunized rat $(\times 480)$.

Fig. 1b Normal bile duct and associated blood vessel in a section from a non-immunized animal $(\times 480)$.

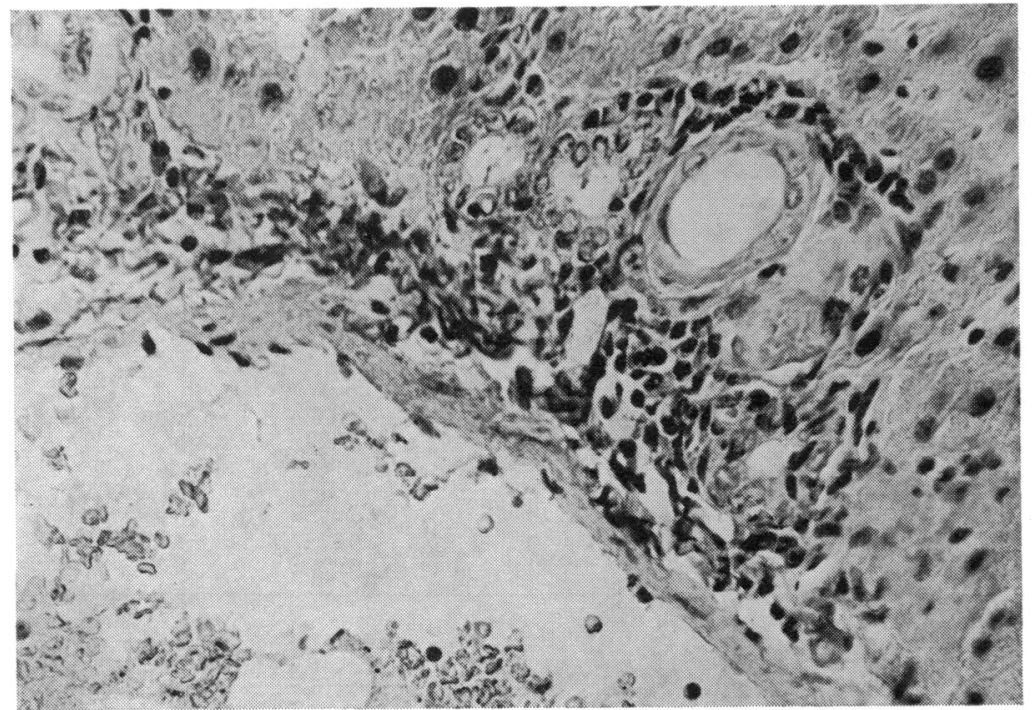

Fig. 2 Swollen, distorted, and reduplicated bile ducts, with loss of nuclear detail, periductular fibrosis and lymphocytic infiltration. There appears to be complete fibrotic occlusion of one of the ducts; section from a directly immunized rat $(\times 480)$. 
the normal numbers of lymphocytes present in the portal tracts of other groups appeared closely related to the fibrotic reaction. No apparent increase in lymphoid infiltration of the liver was found in any of the animals injected with spleen cells.

An increase in the number and size of Kupffer cells appeared more directly related to the adjuvant treatment, though it was not found in group D. Kupffer cells showed no apparent correlation with fibrosis or bile duct damage.

It should be noted that the liver lesions described were more apparent in groups aged between 5 and 6 months at the time of sacrifice compared with groups aged only 2,3 , or 4 months at this time. Correspondingly, immunization commenced later (at 3 months) in the animal groups most affected. All animals in both control groups were 6 months old at the time of sacrifice. This would tend to lessen the differences from the immunized series so that the histological abnormalities actually found are thought to be correspondingly more significant.

\section{PULMONARY LYMPHOCYTIC INFILTRATION}

This infiltration was dominantly peribronchial in distribution, especially in relation to the larger bronchi (Fig. 3 and Table III). In animals showing an increase in peribronchial or alveolar lymphocyte accumulation an increase in the frequency of peribronchial germinal centres was noted and the lymphoid cells often breached the continuity of the bronchial mucosa. Extensive parenchymal (alveolar) infiltration with lymphocytes was present in three out of six of the animals in group B, one out of six of group $F$, and two out of 11 of the animals in group G. Infiltration was not seen in any of the

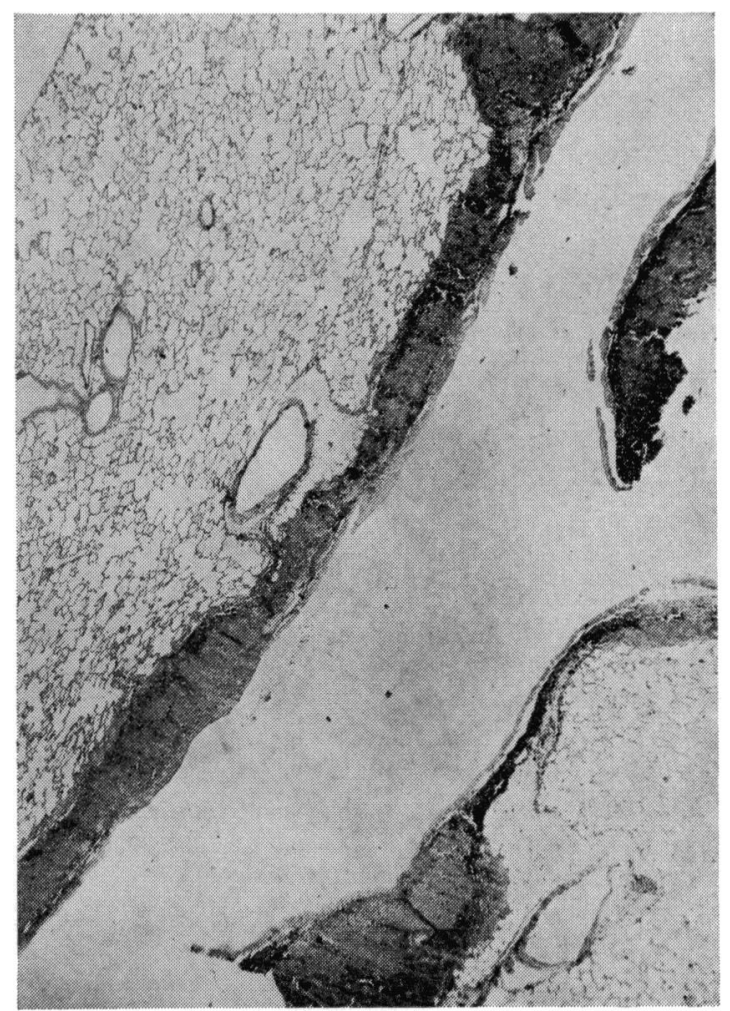

Fig. 3 Intense peribronchial lymphocytic accumulation with early germinal centres formed as seen in the direct and transfer immunized animals $(\times 28)$

\begin{tabular}{|c|c|c|c|c|c|c|c|}
\hline \multirow[t]{2}{*}{ Group } & \multicolumn{5}{|c|}{ Mean Pulmonary Lymphocytic Infiltration Scores 1} & \multicolumn{2}{|c|}{ Mean Corrected Weight $(g)^{2}$} \\
\hline & Alveolar & Peribronchial & $\begin{array}{l}\text { Germinal } \\
\text { Centres }\end{array}$ & $\begin{array}{l}\text { Ulceration of } \\
\text { Bronchial } \\
\text { Mucosa }\end{array}$ & Total & Spleen & Liver \\
\hline $\begin{array}{l}\text { Direct Liver } \\
\text { Immunization } \\
\text { A } \\
\text { B } \\
\text { C } \\
\text { D }\end{array}$ & $\begin{array}{l}0 \\
3 \cdot 0 \\
0 \\
0\end{array}$ & $\begin{array}{l}4 \cdot 0 \\
1 \cdot 7 \\
5 \cdot 0 \\
4 \cdot 5\end{array}$ & $\begin{array}{l}2 \cdot 7 \\
1.3 \\
3.0 \\
4 \cdot 0\end{array}$ & $\begin{array}{l}1 \cdot 7 \\
2 \cdot 3 \\
0 \cdot 8 \\
1 \cdot 5\end{array}$ & $\begin{array}{r}8 \cdot 4 \\
8 \cdot 3 \\
8 \cdot 8 \\
10 \cdot 0\end{array}$ & $\begin{array}{l}0.5 \\
0.63 \\
0.40 \\
0.41\end{array}$ & $\begin{array}{l}6 \cdot 8 \\
7 \cdot 7 \\
7 \cdot 5 \\
8 \cdot 2\end{array}$ \\
\hline $\begin{array}{l}\text { Controls } \\
\text { E (untreated) } \\
\text { F (with adjuvant) }\end{array}$ & $\begin{array}{l}0 \\
0 \cdot 4\end{array}$ & $\begin{array}{l}2.4 \\
1.6\end{array}$ & $\begin{array}{l}2.0 \\
0.8\end{array}$ & $\begin{array}{l}0.8 \\
0\end{array}$ & $\begin{array}{l}5 \cdot 2 \\
2 \cdot 8\end{array}$ & $\begin{array}{l}0.36 \\
0.58\end{array}$ & $\begin{array}{l}7 \cdot 2 \\
7 \cdot 7\end{array}$ \\
\hline $\begin{array}{l}\text { Spleen Cell Transfer } \\
\text { G (immunized cells) } \\
\text { H (sonicated cells) } \\
\text { K (normal cells) }\end{array}$ & $\begin{array}{l}1 \cdot 1 \\
0 \\
0\end{array}$ & $\begin{array}{l}3.0 \\
2 \cdot 3 \\
0.8\end{array}$ & $\begin{array}{l}2 \cdot 4 \\
2 \cdot 2 \\
0 \cdot 4\end{array}$ & $\begin{array}{l}1.2 \\
0.6 \\
0.4\end{array}$ & $\begin{array}{l}7.7 \\
5 \cdot 1 \\
1 \cdot 6\end{array}$ & $\begin{array}{l}0 \cdot 42 \\
0 \cdot 37 \\
0 \cdot 32\end{array}$ & $\begin{array}{l}9 \cdot 3 \\
8 \cdot 0 \\
8 \cdot 5\end{array}$ \\
\hline
\end{tabular}

Table III Supplementary findings in treated and control groups of rats

${ }^{1}$ Scoring: doubtful positive $=1$; positive $=2$; strong positive $=4$; very strong positive $=6$. ${ }^{2}$ Mean spleen and liver weights for all groups are corrected to a standard body weight. 
remaining groups, in all of which the alveoli appeared entirely normal. The assessment for pulmonary lymphocytic infiltration in total correlated with direct liver immunization and with transfer of whole immunized cells. There was no correlation with transfer of sonicated cells or with injection of adjuvant alone.

\section{CORRECTED SPLEEN AND LIVER WEIGHTS}

Mean organ weights for each group were corrected to a standard body weight of $210 \mathrm{~g}$ (the overall mean of the animals studied). Some increase in corrected mean spleen weight was noted in all immunized series including group $G$ (transfer of whole immunized spleen cells) but the differences from the untreated control group were mostly small. The animals treated with adjuvant (group F) also showed moderate splenomegaly and adjuvant dosage seems likely to account for much of the observed increase in weight. In spite of the altered liver histology noted in the immunized animals, there was no significant increase in corrected liver weight in these groups compared with the control groups.

SKIN TESTS WITH SUPERNATANT OF LIVER HOMOGENATE

After intradermal injection of this preparation a definite increase in skin thickness was noted at 24 hours in groups A and B and this was maximal at 48 hours in comparison with the saline controls. There was slight associated erythema and subsequent mild scabbing at the injection site in some animals. In the remaining groups the findings were variable with weak positive reactions in only a few animals in each group. As a consequence, the mean responses were only slightly increased compared with the means for the corresponding saline injections and with the responses in the two control groups.

\section{Discussion}

The liver lesions produced in rats by prolonged liver immunization are mainly confined to the portal tracts, as described also in similarly immunized mouse series (Scheiffarth, Warnatz, and Mayer, 1967a). The mononuclear cell infiltrate observed in both species may in part be due to adjuvant dosage. However, there is clearly in rats an additional involvement of small and larger bile ducts with periductular fibrosis and mucosal damage.

Transfer of the lesion to syngeneic animals by whole spleen cells suggests a cell-mediated immune response, but since plasma cells will also have been transferred and since lesions of lesser degree were also noted after transfer of sonicated cells, it must be concluded that antibody is an essential component, with damage possibly related in part to deposition of antigen-antibody complexes in relation to bile ducts. This conclusion is at variance with the reported results in mice, in which species the lesion described (mononuclear cell infiltrate) was not observed after transfer of serum.

Transfer of a viral agent seems unlikely to explain the lesions since there was no gross evidence of liver cell damage in the rat series, and in general the recipients of repeated liver-immunized spleen cells showed less marked liver damage, especially after sonicated material, than did the directly immunized animals.

Rather surprisingly, it appears that liver damage was more marked after immunization with syngeneic than homologous liver, indicating that a true autoimmunization against liver constituents was involved. It seems possible that a similar process could occur after nonspecific liver damage combined with an adjuvant stimulus, in human subjects as well as in rats.

Because liver lesions in the rat are dominantly related to the bile duct, the rather imprecise classification of portal triaditis (Stauffer, Sauer, Dearing, and Baggenstoss, 1965) may be inappropriate. There is clearly a resemblance to the lesion described as pericholangitis (Mistilis, 1965) and occurring in human subjects with ulcerative colitis or Crohn's disease, but in the rat lesion supplementary infiltration with polymorphs was conspicuously absent. The findings could also be analogous to those described in the early stages of primary biliary cirrhosis by Rubin, Popper, and Schaffner (1965) and Paronetto, Schaffner, Mutter, Kniffen, and Popper (1964) have reported the finding of antiductular antibodies in this diesaes.

By fluorescence microscopy ${ }^{1}$ with conjugated rabbit anti-rat gamma globulin, localization of immunoglobulin has been noted diffusely in relation to bile ducts and the surrounding fibrotic reaction, but not apparently involving liver cells, However, complement-fixing antibodies against liver antigens have also been detected at low titre in the serum of the immunized animals but not so far in animals after spleen cell transfer. This confirms the earlier finding of Weir (1963), who showed the presence of complement-fixing antibodies to liver in rats after a single injection of liver homogenate or after treatment of rats with $\mathrm{CCl}_{4}$.

In the 'blind' histological assessment of liver lesions reported no definite increase in total numbers of mononuclear cells in the portal tracts was found though preliminary studies immediately following the immunizing course strongly suggested an increase, located especially in areas of developing fibrosis. To some extent, the nonspecific increase in ${ }^{2}$ See footnote on page 7. 
the numbers of lymphoid cells resulting from dosage of adjuvant may be obscuring a true increase of immuno-competent cells at the later time interval. Staining of liver sections by the Unna-Pappenheim method failed to reveal any definite increase in plasma cell numbers.

The variability of the delayed skin reaction to supernatant of the liver homogenate in different immunized groups in this study is not altogether surprising, since there is evidence that in some animal species and with some antigens an initially positive delayed skin reaction to antigen becomes negative, as antibody titres to that antigen begin to rise (Crowle and $\mathrm{Hu}, 1965$ ). Delayed skin reactions in the rat to tuberculin or Freund's adjuvant are evoked with some difficulty, but other reactions involving cellular immunity, such as homograft rejection and graft versus host reaction, can be readily demonstrated (Elkins, 1964; Heslop, 1968). A delayed skin response in comparison with control saline injections and with control groups was clearly present in groups $\mathbf{A}$ and $\mathbf{B}$, and doubtfully present in the remaining immunized and whole cell transfer groups. This finding is consistent with the view that the liver lesion in these animals may have partly resulted from a cell-mediated immune response.

Challenge with liver homogenate supernatant, of peritoneal macrophage cultures from immunized animals, produced a marked increase in macrophage aggregation and clumping in comparison with nonimmunized controls, but this might have related to particulate cellular components of the homogenate, and accordingly formal tests for inhibition of macrophage migration were not undertaken. The use of a supernatant following ultracentrifugation was considered, but would not have been representative of the material used for immunization or skin testing.

The peribronchial lymphocytic infiltration suggests a cell-mediated immune reaction directed against pulmonary as well as liver constituents. Circulating antibody seems unlikely to be involved to a major degree in the lung lesion, since lymphoid infiltration was not significantly increased after transfer of sonicated cells (group $\mathrm{H}$ ) and this finding also excludes viral infection as a sufficient cause. Although germinal centres were obvious, plasma cells were not a feature of the lung lesion. It is suggested that the lung lesion may be a manifestation of entodermal cross reactivity. No abnormality was found in the thyroid or in the small or large bowel, but lymphocytic infiltration in the latter tissues is so prominent normally that a moderate increase in gut-related lymphocytes could easily have been missed. Sear from some of the direct liver-immunized animals did show gastric parietal cell antibodies, in the prelimin- ary assessments ${ }^{1}$. This would appear to support the suggestion of a multiple entodermal cross-reactivity, both antibody and cell mediated. It seems possible that the frequent association of antibodies to both thyroid and stomach in patients with pernicious anaemia and with thyroid disease may also represent cross-reactivity with tissues of similar embryological origin. It is of interest that prolonged immunization of rabbits with rat liver was found to give a broad range of antibodies against a variety of different tissues (Asherson and Dumonde, 1962).

This study was supported by a project grant from the Medical Research Council of New Zealand. My thanks are due to Dr B. Heslop, of the Department of Surgery at the University of Otago Medical School, for making available the inbred rat strains used in this study. Acknowledgement is made to Miss Helen Stevenson for her excellent technical assistance. Miss J. Humm also provided valuable assistance in the early part of this work.

References

Asherson, G. L., and Dumonde, D. C. (1962). Characterization of auto-antibodies produced in the rabbit by the injection of rat liver. Brit. J. exp. Path., 43, 12-20.

Crowle, A. J., and Hu, C. C. (1965). Inhibition of the development of delayed hypersensitivity by treatment with antiserum. $J$. Immunol., 94, 555-562.

Elkins, W. L. (1964). Invasion and destruction of homologous kidney by locally inoculated lymphoid cells. J. exp. Med., 120, 329 . 348.

Heslop, B. F. (1968). Histocompatability antigens in the rat: the AS, strain in relation to the AS, BS and HS strains. Aust. J. exp. Biol. med. Sci., 46, 479-491.

Maclaurin, B. P., and Humm, J. A. (1968). Immunological induction of hepatitis in rats. Proc. Univ. Otago med. Sch., 46, No. 3, 75-77.

Maclaurin, B. P., and Humm, J. A. (1969). Development of an animal model of chronic hepatitis by immunological means. In Proceedings of the 3rd Asian-Pacific Congress of Gastroenterology (Melbourne), pp. 46-54.

Mistilis, S. P. (1965). Pericholangitis and ulcerative colitis. I. Pathology, etiology, and pathogenesis. Ann. intern. Med., 63, 1-16.

Paronetto, F., Schaffner, F., Mutter, R. D., Kniffen, J. C., and Popper, H. (1964). Circulating antibodies to bile ductular cells in various liver diseases. J. Amer. med. Ass., 187, 503-506.

Rubin, E., Schaffner, F., and Popper, H. (1965). Primary biliary cirrhosis. Chronic non-suppurative destructive cholangitis. Amer. J. Path., 46, 387-407.

Scheiffarth, F., Warnatz, H., and Mayer, K. (1967). Studies concerning the importance of mononuclear cells in the development of experimental hepatitis. J. Immunol., 98, 396-401.

Stauffer, M. H., Sauer, W. G., Dearing, W. H., and Baggenstoss, A. H. (1965). The spectrum of cholestatic hepatic disease. J. Amer. med. Ass., 191, 829-837.

Warnatz, H., Scheiffarth, F., Wolf, F., and Schmidt, H. J. (1967). Autoradiographic experiments concerning the importance of mononuclear cells in experimental hepatitis. J. Immunol., 98, $402-406$.

Warnatz, H., Scheiffarth, F., and Schwarz, R. (1965). Tierexperimentelle Untersuchungen zur Pathogenase der chronischen Hepatitis. II. Serologische studien nach Sensibilisierung mit homologen Leberzellfraktionen. Virchows. Arch. path. Anat., 339, 364-371.

Weir, D. M. (1963). Liver autoantibodies in the rat. Immunology, 6, 581-591.

${ }^{1}$ Preliminary antibody studies on serum and snap frozen liver slices of the immunized and transfer immunized animals have been undertaken by Mr K. Couchman of the Palmerston North Medical Research Foundation. This work will be reported separately. 